\title{
THE ADEQUACY OF THE EVIDENCE IN THE CASE OF EVIL CONSPIRACY OF NARCOTICS CRIMINAL REVIEWED BY EVIDENTIARY THEORY
}

\author{
Veronika Sihotang ${ }^{1}$, Widati Wulandari ${ }^{2}$, Erika Magdalena Chandra ${ }^{3}$ \\ 1.2,3Faculty of Law, University of Padjadjaran \\ Email:veronika16001@mail.unpad.ac.id
}

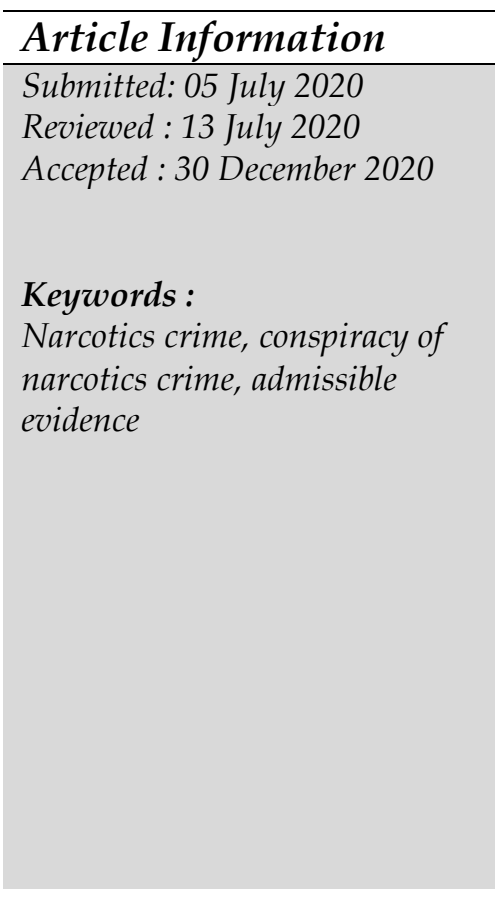

\begin{abstract}
The purpose of this study is to analyze whether the absence of evidence to support the defendant's denial can be the basis to proof personal's guilt and to understand how the quality of the witness testimony can be the basis criminal conviction. This study used the method of judicial normative approach to review and examine the primary data such as Judge's Decision and the secondary data such as related regulation. Rendering a verdict againts person, the Judge decided that a person's guilty should be given enough consideration. The basic of sufficient consideration under Criminal Procedure Code is two legal evidence and the Judge's Conviction. In Conspiracy of Narcotics Criminal Act must be prove by admissible evidence. The involvement in conspiracy is shown by two or more people agree to do narcotics crime. Thus, admissible evidence in conspiracy of narcotics crime become the important issue in some of conspiracy's cases.
\end{abstract}

\section{Introduction}

The president of Republic of Indonesia, Joko Widodo, stated that in a year who died due to narcotics reached of 18,000 people. Center of Research, Data and Information National Narcotics Board of Republic of Indonesia estimates that in one year there are 3, 8 million to 4.1 million abusers of narcotics from total population of Indonesia (Pusat Penelitian Data dan Informasi Badan Narkotika Nasional Republik Indonesia, 2017:2). Based on statistics of UNODC (United Nations Office on Drugs and Crime) up to 2013, there is an increase of drug user (drug-use) and it is estimated almost a quarter of a billion people between the ages of 15 to 64 years which use narcotic in the world (UNODC, 2015:1). This suggests that a criminal offence related to narcotics has occurred widespreadly not only in Indonesia but also around the world. The criminal of narcotics or drug's abuse is not limited to the drug's abuse, but also there are other crimes of narcotics, such as the illicit of narcotics, import, export, planting narcotics, including the evil conspiracy of narcotics. 
The term of conspiracy is not only regulated in the Narcotics Act, but this term is also regulated in Law Number 20 year 2001 about Eradication of Corruption Criminal (UU Tipikor) and the Criminal Code. In the Narcotics law, the term of conspiracy based on Article 1 number 18 of Law Number 35 year 2009 about Narcotic is the act of two or more persons conspired or agreed to make, perform, assist, participate and perform, instruct, encourage, facilitate, give consultation, become a member of an organized crime narcotics or organizing a criminal act of narcotics. So we can conclude that evil conspiracy in the Narcotics Act is the act of two or more persons conspired or agreed to commit the crime of narcotics.

The definition of conspiracy also often has a different interpretation or multiple interpretations. This makes the article about the conspiracy that ever asked to be tested in the Constitutional Court. The arguments of the applicant in the verdict that a conspiracy that also regulated in Article 88 of the criminal code is very multiple interpretations because there is no limit of deeds are categorized as a conspiracy, so according to the arguments of the applicant contrary to the Basic Law. However, in the decision of the Constitutional Court said, it can be categorized as evil conspiracy when two or more persons have the same quality agreed to perform narcotics criminal and conspiracy such as agreement to commit a crime cannot be punished because merely expressing what was in his mind (Decision of Constitutional Court Number 21/PUU-XIV/2016). The definition before does not apply to crimes against the security of the state because it is considered even the preparatory stage can be considered as a crime to prevent the impact or consequences that arise at the stage of beginning implementation.

The agreement or a conspiracy of two or more persons in committing a criminal is must be proved to declare someone do a conspiracy to do a narcotics criminal, including criminal conspiracy, handed over the Narcotics. If the Prosecutor in the sentencing of a person cannot prove the existence of an agreement or a conspiracy of two or more persons commit criminal acts of Narcotics, then the consequences is referring to Article 191 paragraph (1) of the criminal procedure code, it should be acquitted of all his guilt.

In this article will be discussed two rulings that indicate the presence of problems of proof in a criminal conspiracy. The verdict is the Verdict No. 443/Pid.Sus/2016/PN.Smg against the defendant which stated convicted of conspiracy criminal acts of narcotics and sentenced to die. In addition, there are also Decision No. 744/Pid.Sus/2018/PN. North Jakarta. In the verdict the defendants is proven legally and convincingly do criminal acts of "conspiracy to hand over the Narcotics Group I, Not the Plant" and sentenced the defendant to life imprisonment.

The defendant in both cases was the same proven criminal conspiracy narcotics. In Decision No. 443/Pid.Sus/2016/PN.Smg defendants sentenced over criminal conspiracy, sale and purchase transactions of narcotics. As for Decision No. 744/Pid.Sus/2018/PN.Jkt Utr, the defendant is sentenced for criminal conspiracy, handed over the narcotics. Criminal conspiracy in both cases was proven, but there are differences in the adequacy of the evidence that becomes the basis for declaring the occurrence of an agreement or 
conspiracy to commit criminal acts of narcotics. Based on the problems mentioned above, the author intends to discuss about how the enough evidences to declare a person found guilty of criminal conspiracy in terms of evidentiary theory in Indonesia.

\section{Research Methods}

The approach method used by the authors in this study isjudicial normative approach and focuss of this study based on the obscurity of the norm, using analytical approach (analytical approach/analysis). This paper will be analyzed from the point of view of proof in criminal law enforcement. The materials sought in this study is review and examine the primary data such as Decision of the North Jakarta District Court and Decision of Semarang District Court. Furthermore, there is secondary data which used in this study such as the Penal Code, Criminal Procedure Code, and other related materials.

\section{Research Results and Discussion}

\section{A. Conspiracy in a Criminal Offenses in Indonesia}

The rule of conspiracy is found in Article 88 criminal procedure code. Based on this article, as said a conspiracy if two or more persons agreed to commit a crime (Claudio Kermite, 2017:12). The formulation of Article 88 criminal procedure code states "the Conspiracy (samenspanning) is considered to exist, if two or more people agree to commit that crime." From the formulation of this article, the existence of a conspiracy, if there is: two or more people, have agreed, and will do criminal. Conspiracy requires at least 2 (two) people, because if only one (1) person is just a promise to herself alone. So two or more people if they do a negotiation and finally agreed to commit a particular crime, then it can be said the deeds of conspiracy (Claudio Kermite, 2017:12).

Conspiracy or samenspanning to commit one of the crimes stipulated also in the articles 104, 106, 107, and 108 criminal code about concerning treason. By the legislator has been regulated in Article 110 paragraph (1) until paragraph (4) which states that the criminal conspiracy shall be punished with the same punishment with the criminal threatened against the crime itself (Lamintang, 1986: 85). Conspiracy is often equated with the term of special participation. Equated with special participation because the penalty of conspiracy was punished the same with the deeds of the original.

Conspiracy in line with its growth, not only in acts of treason. But also in criminal act of corruption, money laundering, and narcotics. Conspiracy within criminal acts of corruption provided in Article 15 of Law Number 20 year 2001 on Eradication of Corruption that govern the threat of criminal for any person who experiment, coadministered, or conspiracy to do criminal acts of corruption.

The term of conspiracy has a lot of interpretation, so the Article 88 criminal code had been applied for testing to the Constitutional Court because this term is considered to be multiple interpretations. There is no limitation of actions which can be regarded as a 
conspiracy, so that Article 88 of the criminal code is considered to be contrary to the Basic Law. Conspiracy which in Article 88 is originally created for the criminal offense of crimes against state security, which can be done by anyone, as stipulated in article 104, article 106, article 107, and 108 of the criminal code.

Related to the application of review, judges in the Constitutional Court's Decision No. 21/PUU-XII/2016 stated that the conspiracy referred to in Article 88 criminal code is not limited to the agreement of two or more persons, but included also the preparatory acts carried out by people who commit criminal acts. As for the preparatory actions, also includes planning to commit a crime (Decision of Contititutional Court Number 21/PUUXIV/2016). This is contrast with opinion of Ruslan Saleh who said that the existence of a conspiracy can be inferred from descriptions of people who agreed and agreement is a sign that can be seen regarding the conformity of will which is the basis of the agreement.

\section{B. Conspiracy in the Narcotics Crime}

Conspiracy is also regulated in the Narcotics Act. The regulation of the conspiracy is further regulated in Article 132 paragraph (1) of Law Number 35 year 2009 about Narcotics which states thus:

"Experiment or conspiracy to commit criminal acts of Narcotics and Precursors of Narcotics as referred to in Article 111, Article 112, Article 113, Article 114, Article 115, Article 116, Article 117, Article 118, Article 119, Article 120, Article 121, Article 122, Article 123, Article 124, Article 125, Article 126, and Article 129, the culprit shall be punished with same imprisonment accordance with the provisions as referred to in these articles."

The experiment based on the explanation article 132 paragraph (1) Narcotics Law is there are elements of intention, the beginning of the implementation and the completion of the implementation is not solely due to his own will. While, the definition of conspiracy based on Article 1 number 18 of the Law Number 35 year 2009 is the act of two or more persons conspired or agreed to make, perform, assist, participate, instruct, encourage, facilitate, give consultation become a member of a crime organization narcotic, or organize a criminal act of narcotics.

Acts of conspiracy which regulated in Article 132 paragraph (1) Narcotics Act is usually paired with the criminal act stipulated in Article 114 paragraph (2), namely actions: offer for sale, sell off, buy, be an intermediary in the sale and purchase, exchange, submit, or receive the Narcotics. The element of "offering for sale" has the meaning offering something with the intention that shown take. Items for sell must be exist, apart the item is hers or not and there is not a necessity if the goods are physically there in his hand or not (AR Sujono, 2011:255).

The second one, "sell" has the meaning give something to others to obtain payment or receive money. It means to sell when the goods have been provided or at least the items is no longer there with him. The third one, "Buying" intended to obtain something through the redemption (payment) with money, means there must be intent to specific goods that 
will be taken and there should be a payment with the money that value is comparable with the price of the goods (AR. Sujono, 2011:255).

The other point is "Received" is intended to get something because granting from others, as consequence of the granting from the other party is this goods to be hers or at least was in his power. "Being an intermediary in the sale and purchase" is intended as a liaison between the seller and the buyer and on his actions got the services/advantages. "Swap" is intended to hand over the goods and for his actions received the replacement either similar or not similar in accordance with the agreement.

And the last one is "Hand Over", intended to give something to the others. The element of "Hand Over" in the article this is the element of bestandelen. Because of the elements listed, then it raises an obligation to prove. So the consequences are if these elements cannot be proved then the case should be free (Andi Hamzah, 2012:509). As we know that the element of "submit" does not have the understanding or intent, in writing, either in Act No. 35 year 2009 and explanation. So, in proving this element required an interpretation method that can be used the judge in the prove it.

In Decision No. 443/Pid.Sus/2016/PN. Semarang, the defendant was convicted conspiracy criminal sale and purchase of narcotics. The defendant in this ruling declared convicted of conspiracy along with someone (who claims a friend of the defendant). Based on the legal facts which revealed in the trial, there is evidence of the defendant conversation through email. This conversation regarding the delivery of 'generator' from China to Semarang. Other evidence is the shabu-shabu in the generator's machine which imported by the defendant. Such evidence is consistent with presence of a contact number importers 'generator' which is the number of the mobile phone belonging to the defendant. So, it being well-founded for the judge to decide the existence of a conspiracy criminal abuse of narcotics because there is communication that shows an agreement between the defendant and the sender 'generator' who admitted as a friend of the defendant.

In Decision No. 744/Pid.Sus/2018/PN. Jakarta Utara, the defendant was convicted of conspiracy handed over the Narcotics Group I, not the plant. The judge in his ruling declare the defendant guilty of committing criminal conspiracy handed over the narcotics because Defendant was arrested while in the car with other people (the other suspect who was dead because shoot by the officer while trying to escape in the capture) with evidence such as suitcase which containing narcotics. But nevertheless, in the trial there is no evidence that indicates the occurrence of an agreement between the other suspects (owner of the suitcase) with the defendant.

\section{Evidentary Process of Conspiracy Criminal Narcotics}

Evidentary Process is a problem that plays a role important in the process of examination hearings in court. In evidentary process, if there are evidence which enough to prove the guilt of the defendant, then the defendant must be declared guilty of 
committing a criminal offense. But contrary, when the tools of evidence that's not enough to prove the guilt of the defendant, then the defendant should be acquitted of these deeds.

In evidentary process, which is used as a reference to deciding someone's guilt is evidence which is submitted eiher by the Public Prosecutor or the Defendant. Evidence is a thing that has a relationship with an act which with the evidence can be used as evidentiary (Hari Sasangka dan Lily Rosita, 2003:11). Then that evidences rise the judge's belief to the truth of the existence of criminal act that has been done by the defendant.

These in line with Darwan Prinst's opinion which states that evidentiary process is the process to proof an event has occurred and the defendant is guilty to do it, so it must be besought an account (Darwan Prints, 2002:133). The processes of evidence become the process to require and the most important thing to decide of one person is committing a criminal act or not (Andi Hamzah, 2014:249).

Furthermore, according to Yahya Harahap to do evidentiary process, there are some guidelines to do (Yahya Harahap, 2000:217):

1. The public prosecutor as apparatus that is given authority to pose all efforts to prove someone's guilt.

2. On the contrary, the defendant or his legal counsel has the right to knock out the public prosecutor's proof, accordance with the legislation, such as "denial" or rebuttal which is reasoned, with presented a lightens witness or a decharge witness nor the "alibi".

3. Evidentiary process has the function to affirmation of criminal act who performed by the defendant, and at the time set him free from charge which is not proven and to punish him based on charges that has been proven.

The type of legitimate evidence according to Article 183 criminal procedure code shall be further regulated in Article 184 paragraph (1) criminal procedure code which consisted of witness testimony, expert testimony, letters, clue, and the defendant testimony. Then in the process of evidentiary, the evidence above that can be used as a reference to prove a criminal. Every evidence is presented in court and found in courts, basically have the different power of proof. Here's the explanation:

a. Witness Testimony

A witness is a person who can provide information for the investigation purpose, prosecution, and the judiciary on a criminal cases which he heard, he saw, and he experienced with himself (Article 1 number 26 Criminal Procedure Code). From the understanding, some of witness which is known in the law of criminal procedure, that is: a witness who deliberately involved/to see, hear, or participate to experiencing an event. The next witness who accidentally saw/heard or experienced an events. The last one is the witnesses who did not see or hear or experience such events, nevertheless, has expertise to explain such events according to their expertise.

In criminal law procedure, there is some information that should not be heard as witnesses, such as: family by blood or marriage in a straight line from one of the 
parties, the husband or wife even though it has been divorced, the children are not known with certainty that he was 15 years old, and people of amnesia even if they have good memory sometimes (Munir Fuady, 2012:129).

If refers to article 1 number 27 of criminal procedure code which states that the witnesses should he heard, he saw, and he experienced himself. So outside from he hear, see, and he experienced himself cannot be accepted as a legitimate witness statements or cannot be accepted as evidence. A restriction to this rule was changed, since the Verdict of the Constitutional Court No. 65/PUU-VIII/2010, the meaning about witnesses. Witnesses based on that decision of the Constitutional Court stated is not whether by what he saw, heard, or experienced themselves, but rather on the relevance of his testimony in a criminal case that is being processed. So the participation of alibi witnesses, including the witness who heard (testimonium de auditu) being important, although he does not experience that criminal act.

Witness testimony evidences has free strength of evidence, it means that the evidence not be perfect (volledig bewijskracht) or it's not binding and determine (beslissende bewijskracht). Judge based on the strength of the evidence which has been described previously, the judge may determine independently assess the witnesses. Another witnesses, there is witnesses heard or witness de audito. Witnesses heard or witness de audito in accordance with the Decision of the Constitutional Court used as one of the witnesses to be considered. Witnesses heard/witness de audito is the witness that only heard from other people.

The existence of a Witness in the proving the conspiracy of narcotics criminal act, it can be one basis for determining the guilt of the accused. The state of two or more persons reached an agreement as a condition of the fulfillment of the conspiracy (Samuel Saut Martua, 2020:10) can be proved by the testimony of witnesses who heard the agreement between two or more people or witnesses who had themselves experienced an agreement to do a criminal act of narcotics.

b. The Expert Testimony

Expert testimony is information given by a person who has special expertise about the necessary things to make light of a criminal case for the purposes of the examination (Article 1 number 28 Criminal Procedure Code). Things that can be drawn from the definition above is as follows:

1) Expert testimony is information provided by an expert who has "special expertise" about the issue that needed explanation in a criminal case that is being checked;

2) Intent to specific information from the experts so that the criminal case being examined, be light point for the completion of the case examination.

A description of the expert based on Article 180 paragraph (1) of criminal procedure code is said to be requested his presence at the court to give information or explain or clarify the intent in a criminal offence on the basis of expertise in particular. The strength of expert testimony also is free, it same as the strength of other evidence, 
does not bind the judge in making his decision. In proving a conspiracy, expert testimony is also needed in proving the occurrence of the deal.

One of the expert testimony is used as the basic in proving a conspiracy is a description of the ITE expert in Decision No. 443/Pid.Sus/2016/PN. Semarang. The description of the expert stated that there has been conversation between the defendant and the others who claimed his friend through email. In addition, based on expert testimony, this email is own of defendant and info contact the ordering of goods which coming from China is the defendant mobile phones.

c. Proof Letter

Another point of witnesses and experts, the other evidence is proof letter. Proof Letter as referred to Article 187 criminal procedure code as bellow (Article 187 Criminal Procedure Code):

1) Minutes and others documents made in official by or in front of a competent public official, which contain testimony about an event or circumstances which he himself has heard, seen or experienced, accompanied by clear an explicit reason for such testimony.

2) A document made in accordance with the provisions of legislation or a document which is made by an official concerning a matter which falls within the scope of duties for which he is responsible and which is provided as evidence of a fact or a circumstance.

3) Written testimony of an expert which contains an opinion based on his expertise concerning a fact or a circumstance, an example is the visum et repertum.

4) Other documents which are only valid if they have a connection with the contents of the other means of proof.

In Criminal procedure, the strength of the letter evidence is the same with other evidence which is free and the judge has the freedom to assess. Regulation against the letter evidence is contained in Article 184 and 187 of criminal procedure code. Regarding the letter evidence, there are 4 (four) of letter that can be used as evidence, three letters must be made on oath or corroborated by oath, whereas the last one of letter evidence is a letter under the hand.

To prove the conspiracy, the letter evidence in Decision No. 443/Pid.Sus/2016/PN. Semarang is very necessary. Transcript of the conversation between the defendants with the person who claim is a defendant friend through email that indicate the presence of an agreement between the defendant and another person, so the transcript of conversation should be in print-out and legalized by the competent authorities to use as legitimate evidence.

\section{d. Indication}

Indication according to article 188 paragraph (1) of the criminal code is an act, event or circumstance, which because of its consistency, whether between one and another or with the offense itself, signifies that an offense has occured and who the 
prepator is. Furthermore, indication can only be obtained from witness testimony, letters, and description of the defendant.

Indication according to Yahya Harahap must be done by judge with wise, as well as judge needs to first conduct the examination with full accuracy and scrupulosity based on his conscience. Indication must be used with caution. Indication basically rely on other evidence, this evidence is also required in evidentiary process if other evidence otherwise by judge cannot prove the guilt of the defendant. Indication has the same strength with the other evidence, which does not have the strength of binding evidences. It means that the judge in this case is free to determine or assess a situation with a wise and prudent which used become an indication.

An agreement which is important to prove in a conspiracy can be proved by indication or agreement between one evidence with another. For example, proof of conspiracy committed by the defendants in the Decision No. 443/Pid.Sus/2016/PN. Semarang. Between the defendant testimony and other evidence, the invoice or Bill of Leading generator (containing the shabu-shabu) which is sent from the importer email address and there are the defendant mobile number. So the indication showed that the narcotic is the result of orders from the defendant.

e. Testimony of the Accused

Testimony of the accused is the last evidence which recognized in the trial, the examination of the defendant made after the examination of the witness is done. Testimony of accused is what the defendant stated at the court about what he did or what he know or that he experienced himself (Article 189 number 1 Criminal Procedure Code). The testimony of accused is valid if the information has been declared in the trial of court. Testimony of accused which used in the evidentary process is not just contains the "statement of recognition" but also a statement of "denial" of the defendant (Yahya Harahap, 2000:320). Only a Testimony of accused is not enough to prove that the person is guilty, but must be accompanied by other evidence. Testimony of accused has the same strength with the other evidence, which does not have the strength of binding evidences. It means that the judge in this case is free to determine and assess with wise and prudent.

Even if the defendant in the Decision No. 443/Pid.Sus/2016/PN. Semarang has admitted his actions, doesn't mean the defendant automatically guilty. Because it must be supported by the existence of other evidence. Likewise with the Decision No. 744/Pid.Sus/2018/PN. Jakarta Utara, while the defendants deny all his actions, it does not mean the defendant is automatically innocent. Testimony of accused cannot stand alone and must be supported by the existence of other evidence.

Its shows that is the reason of the difficulty to getting evidence to prove the article about conspiracy. As for the evidence to prove that there has been an agreement between two or more people to commit narcotics criminal act. So it makes the number of problems is the lack of evidence to proving the existence of conspiracy (Luthvi Febryka Nola, 2015:113). 
An agreement between two or more people to commit narcotics criminal act not only shown with the conversation to committing a crime. An agreement in conspiracy, according to opinion of Eddy OS Hiariej, must be proof by meeting of mind, it's not necessary with signify words explicitly, but enough with the body language and the sentences that indirectly indicates the existence of an agreement. So, an agreement though not with words explicitly, but can be through body language. But the body language that can signal to start of the deal.

In Decision No. 744/Pid.Sus/2018/PN. Jakarta Utara, the defendant is located along with another suspect in the same place is not enough to prove the absence of meeting of mind through body language. The existence of the defendant and other suspects in the same place also not enough to indicate the presence of an agreement. So to prove the conspiracy, it will be required the body language of the defendant that shows there was an agreement between the defendant and other suspects.

\section{The Consequences of Not Proven an Agreement in Conspiracy of Narcotics Criminal Act}

To proof conspiracy is the same with proof a criminal offense in general. The penal may be imposed to someone if has two absolute requirements, namely sufficient evidence, and Judge's conviction. So, the availability of two items of evidence is not enough to prove the guilt of a person, must be accompanied with the conviction of the judge. This Evidentiary Process that applied in criminal law in Indonesia or known by the verification system of legislation in a negative manner (negatief wettelijk stelsel). That System is although in a case there is sufficient evidence in accordance of the legislation, then the judge is not allowed to impose penalties before obtaining a belief about the guilt of the accused (Yahya Harahap, 2000:319).

Evidence such as that referred contained in Article 183 of the criminal procedure code, which stated thus (Article 183 Criminal Procedure Code):

"A judge shall not impose a penalty upon a person except when with at least two legal means of proof he has come to the conviction that an offense has truly occurred and that it is the accused who is guilty of committing it"

This system of proof is applied because accomplish the purpose of its material truth (materiele waarheid). According to this system of proof, conviction of the judge also can not be the sole basis of punishment; it must be based on a minimum of two evidence in accordance with the mandate of article 183 of criminal procedure code.

The judge can't decided someone is guilty without through evidence processing which presented at the court, and then make the evidence as the basis of a person's guilt. Evidence which used in judge's decision accordance with the provisions of Article 183 of criminal procedure code is a minimum of two legal means of proof. Two legal means of proof is at least two evidence accordance with Article 184 of the criminal procedure code. 
These evidence are not binding, perfect, and forcing and every single evidence has a free to assess. Due to that characteristic, therefore there is no evidence is able to stand on its own, it should be assisted and supported by the other evidence

If the minimum evidence is unfulfilled (legal limit of evidence) that is able to prove the defendant guilty, so this condition is called with a state of reasonable doubt (reasonable doubt) so it must acquit the accused of all guilt (indubio proreo). This means that if in a case there is only one evidence or there is no evidence that can prove the guilt of the defendant, then the defendant should be free. In line article 191 paragraph (1) of criminal procedure code connected with the existence of article 183 of criminal procedure code said If the court is of the opinion that from the results of examination at trial, the guilt of the accused for the acts of which he has been accused has not been legally and convincingly proven, the accused shall be declared acquitted.

As we all know, the judges may decide a person is free if:

1. The evidence which get during the trial is not enough to prove the guilt of the defendant and the guilt of the defendant which is not enough proven and does not conviction of judge.

2. Its not fulfill the minimum of evidence or in other words someone guilt is only supported by one evidence, whereas under Article 183 of criminal procedure code to prove the guilt of a person must be at least two sufficient evidence and the conviction of the judge.

The defendant's fault in indictment at all is not proven, all evidence which presented in the trial whether the witness's testimony, expert testimony, letters, indication, and a description of the accused cannot prove the guilt of the indicted. So that act is not proven legally and convincingly because the judges assess all the evidence which submitted is not sufficient and inadequate to prove the guilt of the indicted. Sufficient evidence to prove the guilt of person basically to achieve a material truth. The adequacy of the evidence is used to find and get at least approach the truth of the material or compelitely truth. The goal is to find who is the perpetrators can be indicted and the person who convicted of it can be blamed (Andi Hamzah, 2012:7).

Based on that explanation, proving the conspiracy committed by the defendants in the Decision No. 443/Pid.Sus/2016/PN. Semarang there are two sufficient evidence to prove the guilt of the defendant. As described, there is a description of the expert, indication, and a description of defendants who have relationships with each other and indicate the presence of agreement or collusion or conspiracy between the defendant and the importer who claiming to be a friend of the defendant. So the judge is convinced that the defendant did conspiracy. Under that evidence, in accordance with the theory of evidence, the judge is convinced to find the defendant guilty and ruling death penalty to the defendant.

The defendant in Decision No. 744/Pid.Sus/2018/PN. North Jakarta also found guilty of a conspiracy to hand over narcotics and convicted a criminal lifetime. As for the evidence which presented at the court is the testimony of two BNN Witnesses and The 
driver of online taxi which does not indicate that there was a conspiracy or agreement between the defendant and the other suspect (the deceased).

Sufficient Evidence is formally based on a system of proof in Article 183 of criminal procedure code has been fulfilled in this case. There is more than one evidence which used as a basis in deciding the conspiracy between the defendant and the other suspect (the deceased). Meanwhile, if seen from the quality of witness testimony and other evidence is not sufficient to prove the guilt of the defendant. Because of the conspiracy or agreement between the defendant with the other suspect (the deceased) cannot be proved. It can be proved through the transcript of the conversation as in the Decision 443/Pid.Sus/2016/PN. Semarang. So the insufficient evidence in decision No. 744/Pid.Sus/2018/PN. North Jakarta to prove the agreement between the defendant and another suspect (the deceased) rise the consequences the defendant should be acquitted

\section{Conclusion}

The adequacy of the evidence in all criminal acts is important role. Adequacy of evidence is one of the requirements to determine the person can be declared guilty or not guilty, therefore the judge has convincingly to make decisions. Then, if the evidence which presented in court not sufficient, so the judge may decide the defendant to be free. The adequacy of the evidence is more important to proving the criminal acts of Narcotics, including criminal conspiracy, handed over the narcotics.

To declare someone's guilty who committing the conspiracy to give narcotics, it is required the evidence sufficient to declare that two or more persons have agreed to commit a criminal act of narcotics. Togetherness of two people or more at the same place it is not enough to prove that there has been an agreement. However two or more people must be proved mutually agreed to commit criminal acts, it can be proved by witnesses who heard a conversation or any proof of the conversation/transcript of the conversation between two or more people agreed to commit criminal acts of narcotics.

\section{Acknowledgements}

The Researcher will say thank you for all those who contributed to this research. Also the researcher thank you to Ibu Widati Wulanda and Ibu Erika Magdalena who supervise this final research to gain a Bachelor Degree in Law at the Faculty of Law, University of Padjadjaran.

\section{BIBLIOGRAPHY:}

\section{Books:}

Chazawi, A. (2008). Hukum Pembuktian Tindak Pidana Korupsi. Bandung: Alumni.

Hamzah, A. (2012). Asas-Asas Hukum Pidana di Indonesia dan Perkembangannya. Jakarta: Sofmedia. 
Hamzah, A. (1985). Pengantar Hukum Acara Pidana Indonesia, Jakarta: Ghana Indonesia.

Sujono, AR. (2011). Komentar dan Pembahasan Undang-Undang Nomor 35 tahun 2009 tentang Narkotika. Jakarta: Sinar Grafika.

Prinst, D. (2002). Hukum Acara Pidana dalam Praktik, Jakarta: Djambatan.

Hari Sasangka dan Lily Rosita. (2003). Hukum Pembuktian dalam Perkara Pidana. Bandung: Mandar Maju.

Siswanto, H. (2012). Politik Hukum dalam Undang-Undang Narkotika (UU Nomor 35 tahun 2009). Jakarta: Rineka Cipta.

Lamintang. (1986). Delik-Delik Khusus: Kejahatan terhadap Kepentingan Hukum Negara. Bandung: Sinar Baru.

Lamintang. (1996). Dasar-Dasar Hukum Pidana Indonesia, Bandung: Citra Aditya Bakti.

Fuady, M. (2012). Teori Hukum Pembuktian (Pidana dan Perdata). Bandung: Citra Aditya Bakti.

Harahap, Y. (2000). Pembahasan Permasalahan dan Penerapan KUHAP (Pemeriksaan Sidang Pengadilan, Banding, Kasasi, dan Peninjauan Kembali. Jakarta: Sinar Grafika.

\section{Journals:}

Claudio A. Kermite, Delik Permufakatan Jahat dalam Kitab Undang-Undang Hukum Pidana dan Undang-Undang Pemberantasan Tindak Pidana Korupsi, Lex Crimen Vol. VI/No. 4/Jun/2017, <http://ejournal.unsrat.ac.id/index.php/lexcrimen/article/view/16449/15964>

Luthvi Febryka Nola, Permufakatan Jahat dalam Tindak Pidana Korupsi, Info Singkat: Vol. VII, No.

24/II/P3DI/Desember/2015, <https://www.google.com/url?sa=t\&source=web\&rct=j\&url=http:/ / berkas.dpr.g o.id/puslit/files/info_singkat/Info\%2520Singkat-VII-24-II-P3DI-Desember-201540.pdf\&ved=2ahUKEwibhfH-

2ozqAhVDjOYKHZmYCzcQFjABegQIAhAB\&usg=AOvVaw2410JFplZOlCK7ljbf_Oc>.

Samuel Saut Martua Samosir, Keterkaitan Percobaan atau Permufakatan Jahat dalam Tindak Pidana Narkotika, Fairness and Justice, Vol. 16, No. 2 (2018), <http://jurnal.unmuhjember.ac.id/index.php/FAJ/article/view/2043>. United Nation Office on Drugs and Crime (UNODC), Status and Trend Analysis of Illicit Drug Markets, <https://www.unodc.org/documents/wdr2015/WDR15_Drug_use_health_conse quences.pdf $>$.

Pusat Penelitian Data dan Informasi Badan Narkotika Nasional Republik Indonesia, Survei Nasional Penyalahgunaan Narkoba di 34 Provinsi tahun 2017,http:/ / www.google.com/url?sa=t\&source=web\&rct=j\&url=http:/ / www.ru mahcemara.or.id/rumahcemara.or.id/2017\% 2520Survei\%2520Nasional\%2520BNN .pdf\&ved=2ahUKEwi4tlLr3L7oAhW4zgGHatCBOEQFjABegQIARAB\&usg=AOvVaw2YcQtouOuD19NF_PTODNPK 